Jurnal Ilmu Sosial dan Pendidikan (JISIP)

Vol. 5 No. 3 Juli 2021

Terakreditasi Peringkat 5 (No. SK: 85/M/KPT/2020)

e-ISSN : 2656-6753, p-ISSN: 2598-9944

DOI: 10.36312/jisip.v5i3.2178/http://ejournal.mandalanursa.org/index.php/JISIP/index

\title{
Pantun Sebagai Media Pendidikan Karakter Dalam Pembelajaran Bahasa Indonesia
}

\author{
Ali Wardana ${ }^{1}$, Abdul Wachid, B.S. ${ }^{2}$ \\ ${ }^{1,3}$ UIN Prof. K.H. Saifuddin Zuhri Purwokerto \\ ${ }^{2}$ UIN Prof. K.H. Saifuddin Zuhri Purwokerto
}

\begin{abstract}
Article Info
Article history:

Article Reseived : 17 July 2021

Publication: 20 July 2021
\end{abstract}

\section{Kata Kunci:}

Menulis Pantun, Media

Pendidikan Karakter

\section{Article Info}

Article history:

Article Reseived : 17 July 2021

Publication: 20 July 2021

Keyword:
Writing rhymes, Media,
Character Education.

\begin{abstract}
ABSTRAK
Karakter dipandang sebagai pondasi bagi setiap manusia, maka karakter harus sedini mungkin ditanamkan kuat kepada anak-anak diantaranya melalui pendidikan karakter. Pendidikan karakter tingkat Madrasah Ibtidaiyah/ Sekolah Dasar terdapat aspek religius, moral, kejujuran, sopan santun, menghargai orang lain, dan nilai luhur lainya. Kenyataan di lapangan bahwa peran lembaga pendidikan dan guru akan pentingnya penanaman nilai karakter moral belum maksimal karena pelbagai faktor. Pada Madrasah sebetulnya sudah ada upaya penanaman nilai karakter melalui mata pelajaran akidah akhlak, namun pada praktenya belum dapat mencapai hasil yang memuaskan, hal ini perlu didukung dengan penanaman nilai karakter pada mata pelajaran lain diantaranya Bahasa Indonesia pada materi pantun. Nilai-nilai karakter dapat ditanamkan dengan disisipkan dalam materi puisi lama(pantun agama dan nasihat) yang didalamnya terdapat nilai-nilai luhur warisan bangsa antara lain nilai agama dan budi pekerti. Tujuan penulisan ini diharapkan materi pantun dapat menjadi media penanaman karakter siswa di Madrasah Ibtidaiyah melalui maknal pesan moral yang tersurat dan tersirat dalam isi pantun. Penelitian yang ditulis menggunakan teknik observasi, wawancara dan dokumentasi sebagai hasil dari metode analisis kualitatif yang dipakai. Hasil penelitian menunjukan;(1) pembelajaran pantun dapat menanamkan nilai karakter bagi siswa antara lain demokratis, religius, tanggug jawab, jujur, mandiri, kreatif, pembiasaan literasi membaca dan aktif berkomunikasi; (2) usaha untuk mengatasi masalah dalam proses belajar mengajar Bahasa Indonesia materi pantun sebagai penanaman nilai karakter dengan cara mengelola dan mengorganisasi interaksi siswa dengan siswa lain, siswa dengan guru, strategi, serta penggunaan media pembelajaran yang tepat.
\end{abstract}

\begin{tabular}{l} 
Abstract \\
Character is seen as the foundation for every human being, so the character must \\
be strongly instilled in children as early as possible through character education. \\
Character education at the Madrasah Ibtidaiyah/Elementary School level has \\
religious, moral, honesty, courtesy, respect for others, and other noble values. The \\
reality on the ground is that the role of educational institutions and teachers \\
regarding the importance of inculcating moral character values has not been \\
maximized due to various factors. In Madrasas, there have actually been efforts to \\
inculcate character values through moral aqidah subjects, but in practice, they have \\
not been able to achieve satisfactory results, this needs to be supported by planting \\
character values in other subjects including Indonesian in rhyme material. \\
Character values can be instilled by inserting them in old poetry material (religious \\
rhymes and advice) in which there are noble values of the nation's heritage, \\
including religious values and character. The purpose of this writing is to hope that \\
the rhyme material can be a medium for inculcating student character in Madrasah \\
Ibtidaiyah through the explicit and implicit meanings/moral messages in the \\
contents of the rhyme. The research was written using observation, interview, and \\
documentation techniques as a result of the qualitative analysis method used. The \\
results of the study show; (1) learning rhymes can instill character values for \\
students, including democratic, religious, responsible, honest, independent, \\
\hline
\end{tabular}


creative, habituation of reading literacy and active communication; (2) efforts to overcome problems in the teaching and learning process of Indonesian rhyme material as the inculcation of character values by managing and organizing student interactions with other students, students and teachers, strategies, and the use of appropriate learning media.

This is an open access article under the Lisensi Creative Commons Atribusi-BerbagiSerupa 4.0 Internasional (c) (1) (2)

\section{Corresponding Author:}

\section{Ali Wardana}

Universitas Islam Negeri Prof. K.H. Saifuddin Zuhri Purwokerto (UIN Saizu Purwokerto)

Email: aliwardana80@gmail.com

\section{PENDAhULUAN}

Dalam perjalanan hidup manusia kata dan bahasa merupakan kemampuan dasar yang harus dikuasai, kata dan bahasa akan berkembang sesuai situasi, kondisi, dan tempat dimana manusia berada, dilahirkan, dan dibesarkan. Menurut Mustanyir (1988) yang mengutip Oemar Bakry dalam Abdul Wachid dan Kurniawan (2019:2) menerangkan bahwa dalam Islam bahasa sudah diajarkan oleh Allah SWT kepada Nabi Adam berkenaan dengan berbagai nama benda, dan Nabi Adam dapat menyebutkanya. Mustanyir menilai hal tersebut sebagai bukti bahwa sejak semula manusia sudah dibekali kemampuan berbahasa oleh Allah SWT. Disebutkan dalam Al-Qur'an surat Al-Baqarah 31:

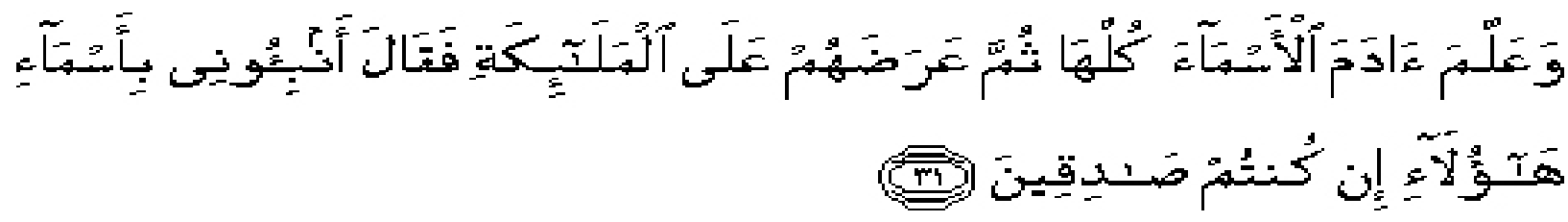

Bahasa, kata, dan tulisan merupakan bagian yang tidak terpisahkan, dengan bahasa kata dapat terucap, kata dan bahasa juga dapat diwujudkan dengan tulisan sebagai jejak karya sastra. Bahasa juga merupakan salah satu unsur utama dari pendidikan, maka pendidikan seyogyanya bukan sekedar memberikan materi pelajaran saja namun juga yang tidak kalah penting adalah penguatan karakter dan moral peserta belajar atau siswa, ketika pendidik hanya terpaku pada tataran menyampaikan materi saja berarti guru baru pada ranah mengajar belum sampai pada ranah mendidik dan membimbing. Realitanya ternyata banyak terjadi penyimpangan- penyimpangan moral yang dilakukan oleh pelajar tidak terkecuali pada usia sekolah dasar, seperti kurangnya sopan santun, tata krama, anggah-ungguh kepada orang lain, serta perilaku kekerasan verbal dan non verbal kepada teman sebaya seperti membully dll. Fenomena tersebut merupakan salah satu indikasi belum berhasilnya suatu pembelajaran dalam mencapai tujuan pendidikan yang kemudian menyebabkan kurang tertanamnya nilai karakter dan moral yang baik bagi siswa.

Karakter merupakan hal dasar yang harus dimiliki oleh semua orang. Karena bersifat dasar dan sebagai pondasi maka penanamanya harus kuat dan mengakar. Berkaitan dengan hal tersebut maka karakter harus ditanamkan sedini mungkin khususnya kepada anak-anak salah satunya melalui pendidikan karakter. Akan tetapi peran lembaga pendidikan dan perangkat di dalamnya termasuk guru terhadap pentingnya penanaman nilai karakter serta moral belum sepenuhnya tercapai karena pelbagai faktor. Pada Madrasah sebetulnya sudah ada upaya penanaman nilai karakter yaitu melalui mata pelajaran akidah akhlak, namun pada kenyataanya belum mencapai hasil yang maksimal, maka hal ini juga perlu didukung dengan penanaman nilai karakter pada mata pelajaran lain diantaranya Bahasa Indonesia.

Jika menengok pendidikan karakter pada anak usia Madrasah Ibtidaiyah/ Sekolah Dasar disitu terdapat aspek religius, moral, kejujuran, sopan santun, menghargai orang lain, dan nilai luhur lainya 
yang bersifat global, nilai-nilai ini dapat ditanamkan dengan cara disisipkan dalam pembelajaran Bahasa Indonesia dalam materi pantun khususnya pantun agama dan pantun nasihat. Dalam pantun agama dan nasihat terdapat nilai-nilai karakter luhur warisan bangsa yang didalamnya terdapat nilai agama dan budi pekerti, melalui materi ini diharapkan dapat menjadi media penanaman karakter kepada siswa jenjang Madrasah Ibtidaiyah dan atau Sekolah Dasar melalui makna yang tersurat dan tersirat dalam isi pantun.

Pembelajaran bahasa Indonesia pada materi pantun seharusnya bukan hanya menjadi ritual belajar yang sekedar dilewati dan diajarkan saja tanpa mempunyai tujuan dan makna. Pembelajaran pada materi pantun dapat dijadikan sebagai sarana untuk pembentukan juga penanaman nilai karakter moral dalam pendidikan.

Berdasar kegelisahan di atas maka penulis menganggap perlu ada penanaman pendidikan karakter melalui pembelajaran pantun di Madrasah Ibtidaiyah Negeri 3 Purbalingga agar mempunyai makna pendidikan karakter yang mengakar.

\section{METODE PENELITIAN}

Metode yang dipergunakan dalam penelitian ini adalah menggunakan pendekatan deskriptif kualitatif. Informasi yang diperoleh dari pendekatan ini berbentuk kata yang kerap dipakai untuk menciptakan teori baru yang muncul dari hipotesis-hipotesis. Objek dari penelitian ini ialah proses kegiatan belajar mengajar pada materi pantun. Lokasi penelitian ini yaitu pada Kelas V B MIN 3 Purbalingga yang terletak di Jalan DPU Nomor 05, Desa Wirasaba, Bukateja, Purbalingga. Sumber penggalian data penelitian ini adalah Guru kelas 5 B, siswa kelas 5 B dengan jumlah 25, serta Kepala Madrasah yang berperan sebagai narasumber dan penyedia informasi untuk mendapatkan informasi yang bersifat umum. Penelitian ini ditentukan pada kelas 5 karena materi/ pembelajaran pantun ada pada tema 4 dan 6. Sugiyono (2012:305) menyebutkan pentingnya peneliti dalam metode kualitatif karena instrumen dalam penelitian ini adalah peneliti sendiri. Peneliti di sini mempunyai peran sebagai key instument yang sangat penting dalam penyusunan pedoman/ skenario wawancara dan pengamatan yang digunakan dalam penelitian.

Penelitian ini mempergunakan teknik pengamatan langsung/ observasi, wawancara untuk menggali informasi dan teknik dokumentasi. Analisis terhadap data digunakan untuk merangkum data yang dikumpulkan dengan benar dan dapat diuji. Teknik analisis model kualitatif dipilih dalam penelitian ini. Teknik analisis data ini terbagi menjadi tiga rangkaian kegiatan, antara lain reduksi data, penyajian, dan penarikan kesimpulan/verifikasi seperti model Miles dan Huberman. Dalam pengujian keabsahan dan kredibilitas data menggunakan triangulasi sumber dengan teknik pengumpulan yang sama untuk mendapatkan data dari sumber yang berbeda dan triangulasi teknik dengan menggunakan beberapa teknik pengumpulan data yang berbeda untuk mendapat data dari sumber yang sama.

\section{HASIL PENELITIAN DAN PEMBAHASAN}

\subsection{Hasil Penelitian}

\section{Penanaman nilai Karakter oleh guru}

Nilai karakter moral perlu ditanamkan kepada siswa dalam proses belajar mengajar, hal ini berguna menyeimbangkan aspek kognitif siswa, afektif, dan psikomotoriknya, hal ini penting agar peserta didik mempunyai tingkah laku serta karakter moral yang baik pula sampai pada akhirnya akan membawa manfaat bagi siswa tersebut dan manfaat bagi orang lain. Selain itu guru juga perlu menjadi contoh yang baik bagi siswa karena siswa pada jenjang Madrasah Ibtidaiyah atau sekolah dasar secara umum masih dalam fase meniru dan mencontoh sesuatu yang didengar dan dilihat. Guru juga harus melatih dan membiasakan diri secara efektif bagaimana caranya menanamkan nilai karakter melalui pembelajaran pantun. Strategi yang dipakai guru yaitu dengan menanamkan nilai karakter secara langsung, yaitu dengan langsung 
disampaikan kepada siswa dalam pembelajaran nilai- nilai moral apa yang ada atau terkandung dalam pantun agama dan pantun nasihat. Penyampaian nilai karakter moral dalam makna pantun ini dilakukan dengan efek penekanan dan penguatan yang positif yaitu dengan menyampaikan berulang-ulang makna yang terkandung dalam isi pantun. Zuriyah(2011:222) memberi pengertian bahwa pendidikan moral merupakan pendidikan dalam dan luar sekolah dengan mengorganisasi serta membuat lebih sederhana sumber-sumber moral yang disajikan tentunya mempertimbangkanan aspek psikologis untuk tujuan pendidikan.

Madrasah Ibtidaiyah mempunyai fungsi yang penting untuk menghasilkan generasi yang bermoral sejak dini dan berakhlakul karimah yang pastinya akan sesuai dengan masyarakat, pada kurtilas atau kurikulum 2013 pendidikan karakter moral sebetulnya tidak berdiri sendiri seperti pada KTSP, namun sudah terintegrasi pada seluruh mata pelajaran melalui model tematik selain juga pada kegiatan ekstrakurikuler antara lain pramuka.

\section{Langkah Pembelajaran}

Pelaksanaan kegiatan belajar mengajar pada materi pantun yang menanamkan nilai karakter moral di kelas 5 B MIN 3 Purbalingga dilakukan dengan langkah-langkah pendahuluan, inti, dan penutup. Berikut adalah beberapa langkah yang terlihat selama proses pengamatan/ observasi langsung yang dilakukan peneliti. (1) Kegiatan Awal, pada kegiatan ini guru mengucapkan salam, diteruskan membuka pembelajaran dengan berdo'a, kemudian menyapa peserta didik dengan senyum, memberikan stimulus pembelajaran, melakukan presensi, dan tentunya menyampaikan tujuan apa yang akan dicapai dalam pembelajaran tersebut. (2)Kegiatan Inti, pada kegiatan ini diawali dengan penjelasan materi pantun oleh guru dimulai dari pengertian, kemudian srtuktur dari pantun, serta memberi contoh pantun agama dan nasihat yang kemudian guru meyajikan konflik moral dengan cerita yang temanya berkaitan dengan makna/isi pantun sebagai cara menanamkan nilai karakter yang terkandung dalam pesan/ isi pantun tersebut. (3) Kegiatan akhir atau penutup, pada proses ini guru memberikan klarifikasi dan kemudian bersama-sama membuat kesimpulan serta penguatan. Pada proses akhir ini guru memberikan tugas sebagai evaluasi pembelajaran yaitu dengan menugaskan siswa untuk membuat pantun nasihat atau pantun agama, hasil dari pekerjaan ini kemudian dipresentasikan oleh siswa di depan kelas kemudian pantun tersebut dibacakan serta mencoba untuk mengungkapkan pesan/isi yang ada dalam pantun yang telah di bacakanya.

Proses pembelajaran di Kelas 5 B MIN 3 Purbalingga di atas terperinci menjadi beberapa tahap pembelajaran antara lain. (1) Penjelasan, pada langkah ini guru menjelaskan materi pembelajaran pantun, antara lain pengertian pantun, jenis-jenis pantun, struktur, ciri-ciri, dan memberikan contoh, antara lain:

Mengayuh rakit menuju hulu

Berenang ke tepian

Bersakit-sakit dahulu

Senanglah kemudian

(2) Pengaitan makna pantun dengan nilai karakter/moral yaitu dengan cara mengungkap pesan dan makna yang tersurat ataupun tersirat dalam isi pantun, yang kemudian guru mengaitkannya dengan nilai karakter moral yang muncul. Dalam kegiatan ini dilakukan dengan menyajikan sebuah cerita yang menarik antara lain, kisah guru sendiri yang harus bersekolah berpuluhpuluh tahun yang akhirnya dapat mencapai cita-cita menjadi seorang guru, hal ini akan menarik perhatian siswa karena yang dicontohkan adalah orang yang mereka kenal. Hal ini menanamkan karakter percaya diri dan bekerja keras. (3) Penekanan, pada kegiatan ini disajikan masalah moral yang berkaitan dengan nilai yang ada dalam isi pantun, misalnya ada sebauah nyanyian pantun dari daerah Kalimantan Timur:

Aduh- aduh Siti Aishah

Mandi di sungai rambutpun basah 
Tidak sembahyang tidak puasa

Di dalam kubur mendapat siksa

Guru memberikan penjelasan bahwa hukum shalat/smbahyang dan puasa adalah wajib serta tidak boleh ditinggalkan karena merupakan rukun Islam. Tetapi kenyataanya dapat dilihat banyak Masjid yang sepi jama'ah ketika shalat, kemudian dikuatkan lagi dengan ayat AlQur'an misalnya pada surat An-Nisa ayat 103:

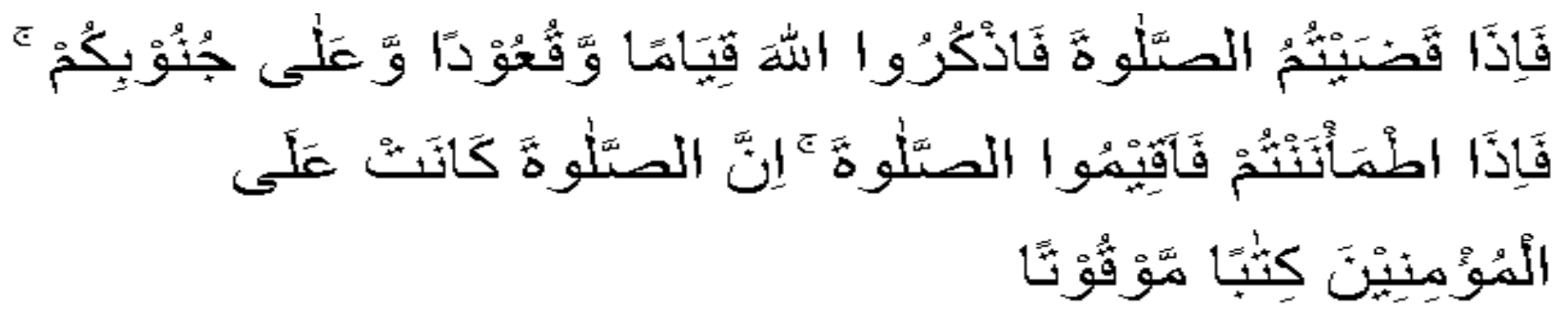

Dijelaskan dan ditekankan dalam ayat ini yang intinya adalah kita harus selalu mengingat Allah pada saat berdiri, duduk, dan berbaring, serta kewajiban shalat bagi orang-orang yang beriman. Kemudian menyangkut puasa guru memberikan dalil dalam Surat Al-Baqarah ayat 183:

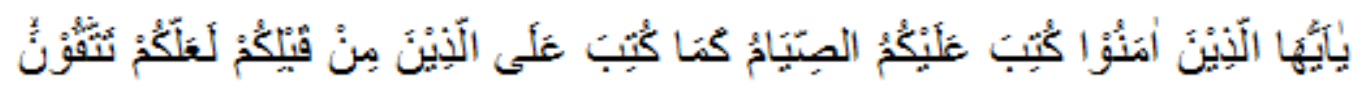

Dijelaskan dan ditekankan bahwa puasa bersifat wajib bagi semua umat islam agar menjadi orang yang bertaqwa. Hal ini perlu ditanamkan kepada peserta didik antara lain hukum shalat dan puasa adalah wajib bagi setiap muslim jika kita meninggalkan kewajiban maka ancaman dari Allah adalah siksa kubur/ neraka. Pantun lain yang diberikan adalah:

Kakak gendong adik pemalu

Adik pemalu seperti Bapak

Jangan lancang kepada ibu

Sebab surga ada di telapak

Pada pantun ini guru menjelaskan bahwa kita harus selalu menghormati Ibu kita, tidak boleh lancang dan selalu menyayanginya karena kunci surga adalah pada Ibu atau orang tua kita, kemudian diberikan penguatan dengan kalimat "al-jannatu tahta aqdam al-ummahat", dan kemukakan hadist dari Abu Hurairah ra yang yang diriwayatkan oleh Bukhari r.a. mengisahkan tentang ada salah satu sahabat yang bertanya kepada Nabi Muhammad SAW tentang kepada siapa harus berbakti, yang kemudian dijawab "Ibumu" oleh Rasulullah sebanyak tiga kali kemudian baru "Ayahmu". Dengan penyajian dalil ini guru menjelaskan bahwa menghormati seorang Ibu sangat dianjurkan oleh Rasulullah SAW, bahkan sampai disebutkan tiga kali baru kemudian seorang Ayah yang harus kita berbakti kepadanya. Hal ini dapat menanamkan karakter berbakti kepada orang tua. Kemudian dilanjutkan dengan (4) Pengulangan, pada kegiatan ini mempunyai tujuan untuk menguatkan ingatan siswa terhadap nilai karakter yang terkandung didalamnya, guru mengulang materi dan meminta siswa dengan membaca berulangulang dan menulisnya, kemudian barulah diberikan beberapa pertanyaan yang berkaitan dengan pesan pantun tersebut. Misalnya Apa yang kalian lakukan jika Ibu menyuruhmu? Siapa yang melahirkan dan membuatmu menjadi seperti sekarang? Bagaimana jika tidak ada seorang Ibu di dunia ini?. Penekanan ini dilakukan secara berulang-ulang agar memberikan penguatan dan penekanan yang positif dari nilai karakter yang yang ada dalam isi pantun sampai tercapainya hasil pembelajaran. (5) Kemudian tahap refleksi, pada tahap ini dilakukan dengan membuat resume dan latihan secara bersama-sama. (6) Pemberian tugas, pemberian tugas ini diberikan dengan catatan siswa harus mengetahui pesan moral dari pantun yang dibuat hal ini dapat dibantu oleh guru dengan cara mengkomunikasikanya dengan siswa tentang apa amanat yang akan disampaikan pada pantun yang akan dibuatnya. 
Langkah-langkah guru di atas membuktikan pembelajaran yang dilakukan oleh guru kelas 5 B MIN 3 Purbalingga menggunakan metode pembelajaran ekspositori dialogis, penugasan, serta problem solving. Pembelajaran dengan memadukan beberapa metode menjadikan suasana belajar lebih menyenangkan, antara lain pendekatan dialogis dan pemberian tugas. Selain itu guru juga mencontohkan langsung untuk memperkuat nilai moral yang telah ditanamkan, antara lain guru datang tepat waktu bahkan sebelum siswa masuk ke kelas, selalu mengucapkan salam, dan berbicara dengan sopan. Hal tersebut sesuai pendapat Zuriah(2011:75-76) yang menjelaskan bahwa pendekatan penanaman nilai, yaitu memberikan contoh keteladanan, penguatan positif dan negatif, simulasi, dan bermain peran dapat meningkatkan keberhasilan siswa dalam pendidikanmoral.

\subsection{Pembahasan}

\section{Nilai-nilai Karakter Moral yang Muncul dalam Pembelajaran Pantun}

Pembinaan watak kepada peserta didik dapat diterapkan dengan menggunakan pengajaran Bahasa dan Sastra Indonesia, sesuai apa yang disampaikan oleh Muslich(2014:212). Maka karena pantun termasuk sastra Indonesia lama, juga dapat dijadikan sebagai sarana penanaman nilai karakter. Pembelajaran pada materi pantun sebagai media menanamkan nilai karakter telah dilakukan di MIN 3 Purbalingga dan dapat memunculkan nilai-nilai karakter moral selama proses pembelajaran antara lain:

(1) Religius, aspek ini terlihat pada proses pendahuluan yaitu pada saat guru mengucapkan "assalamu'alaikum" serta membaca do'a. Dengan mengucapkan salam dan dibalas salam oleh siswa, kemudian berdo'a bersama berarti guru telah menanamkan sikap religius. (2) Demokratis, karakter ini tampak pada inti pembelajaran yaitu pada saat guru memberikan sebuah pertanyaan berupa permasalahan atau konflik moral dan siswa dapat memberi jawaban secara bebas. (3) Berbakti, hal ini dapat dilihat pada awal ketika akan masuk kelas dan meninggalkan kelas semua siswa berjabat tangan dan mencium tangan guru, kemudian pada saat siswa mau mengerjakan tugas yang diberikan dan membacakanya di depan kelas. (4) karakter jujur, karakter ini terlihat saat guru mengajukan pertanyaan kemudian siswa dapat menjawabnya dengan jujur. (5) Tanggung jawab, percaya diri, kerja keras dan mandiri, karakter moral ini terlihat sewaktu guru meminta siswa untuk membuat pantun dan membacanya di depan teman-temanya satu kelas. Pada kegiatan ini berarti siswa bertanggung jawab dengan apa yang dikerjakanya. Serta dapat percaya diri dan mandiri karena mengerjakan sendiri dan mau maju ke depan. (7) Kreatif, hal ini tampak ketika peserta didik mengerjakan pantun dengan kreatifitas dan kemampuanya. (8) Gemar membaca, hal ini terlihat ketika siswa membaca pantun berulang ulang sesuai yang diminta oleh guru.

\section{Permasalahan yang muncul dan Upaya Mengatasi}

Dalam setiap pelaksanaan pembelajaran pasti menemui beberapa kendala. Beberapa kendala dan cara mengatasi kendalanya dalam pembelajaran ini antara lain: (1) Guru mengalami sedikit kendala atau kesulitan ketika mengaitkan nilai karakter moral dalam pembelajaran pantun dengan cerita yang hendak disampaikan, masalah ini dapat diatasi oleh guru melalui cara mengajar dari pola sederhana menuju yang kompleks, yakni guru memberi penjelasan makna ataua pesan dalam pantun, barulah guru mengidentifikasi nilai karakter moral yang ada dalam pantun tersebut kemudian menghubungkannya dengan cerita, cerita ini dimaksimalkan untuk menguatkan dan menekanan nilai karakter moral yang ada. (2) Permasalahan waktu belajar, kendala ini muncul karena pada proses ini guru memerlu kan waktu lebih untuk mengulang bahasan isi pantun sebagai bentuk penguatan daya ingat siswa. Masalah ini dapat diatasi dengan mengoptimalkan waktu pembelajaran yang ada serta dapat mencari jam tambahan diluar jam pelajaran. (3) Kendala personal, yaitu kemampuan guru untuk merencanakan dan membelajarkan pantun dengan menanamkan nilai karakter di dalamnya dengan menggunakan pembelajaran yang menyenangkan, selain itu kemampuan guru dalam mengaitkan sebuah cerita 
dengan pesan karakter moral yang terkandung dalam isi pantun juga menjadi kendala tersendiri. Namun kendala tersebut dapat diatasi oleh guru dengan cara menambah bacaan kemudian melakukan diskusi dengan guru lain untuk mendapatkan kritik, masukan dan ide untuk dapat melakukan pemelajaran yang lebih baik lagi.

\section{KESIMPULAN}

Kesimpulan dari penelitian ini diantaranya (1)Guru paham akan penanaman nilai karakter moral dalam pembelajaran pantun terhadap siswa, hal ini dibuktikan dengan kegiatan pembelajaran pantun dengan menggunakan langkah-langkah yang urut antara lain penjelasan, menghubungkan isi pantun dengan nilai karakter, melakukan penguatan, pengulangan, refleksi, dan evaluasi dengan cara member tugas siswa. Langkah-langkah tersebut juga membuktikan bahwa guru menggunakan metode pembelajaran ekspositori yang digabungkan dengan pendekatan dialogis, tanya jawab, penugasan, dan pemecahan masalah. (2) Pantun dapat digunakan sebagai media penanaman pendidikan karakter bagi siswa madrasah Ibtidaiyah (3) Nilai-nilai karakter moral yang muncul selama proses pembelajaran diantaranya adalah religious, demokratis, kerja keras,, jujur, tanggung jawab, percaya diri, kreatif, mandiri, dan gemar membaca.

\section{UCAPAN TERIMAKASIH}

Penulis menyampaikan terimakasih kepada dosen mata kuliah Pengembangan Bahasa Indonesia Dr. Abdul Wachid, B.S. yang telah membimbing saya dalam penelitian ini, penulis berharap penelitian ini menjadi pengalaman dan pembuka pintu untuk penulisan-penlisan penelitian selanjutnya yang mudah-mudahan akan mendatangkan manfaat baik bagi penulis sendiri ataupun orang lain

\section{DAFTAR PUSTAKA}

Kementerian Agama RI, “Al-Qur’an dan Terjemah”, Bandung: Syaamil Qur'an, 2012.

Wachid, B.S., Abdul, Kurniawan, Heru. Kemahiran Berbahasa Indonesia. Yogyakarta: Citra Buku, 2019.

Wachid, B.S., Abdul., dkk,. Creative Writing, Yogyakarta: SKSP (Sekolah Kepenulisan Sastra Peradaban), 2020.

Ningsih, Tutuk. Pendidikan Karakter Teori\&Praktik. Banyumas: Rumah Kreatif Wadas Kelir, 20021.

Mulyana, Rohmat. Mengartikulasikan Pendidikan Nilai. Bandung: Alfabeta, 2011

Muslich, Masnur. Pendidikan Karakter : Menjawab Tantangan Krisis Multidimensional. Jakarta: Bumi Aksara, 2014

Nadjua A.S. (Tanpa Tahun). Buku Pintar Puisi \& Pantun. Surabaya: Triana Media.

Sugiyono. Metode Penelitian Pendidikan:Pendekatan Kuantitatif, Kualitatif, dan R\&D. Bandung: Alfabeta, 2012.

Sugono, Dendy (Ed.). Buku Praktis Bahasa Indonesia Jilid 1. Jakarta: Departemen Pendidikan Nasional, 2009.

Zuriah, Yustiani (Ed.). Pendidikan Moral dan Budi Pekerti dalam Perspektif Perubahan: Menggagas Platform Pendidikan Budi Pekerti Secara Kontekstual dan Futuristik. Jakarta: Bumi Aksara, 2016.

Camalia, D., Ikhwan,K., W., dkk. "Pendidikan Nilai-Moral Melalui Pembelajaran Pantun pada Siswa Sekolah Dasar”. Pamator. 9 , no. 2(Oktober 2016): 103-108(diakses 3 Juni 2021).

Koswara, Dedi., “ Nilai-nilai Pendidikan Karakter Bangsa Dalam Carita pantun Mundinglaya

Dikusumah : Kajian Struktural Semiotik dan Etnopedagogi”. (November 2008). Diakses 3 Juni 2021. 
Hasim, Abdul., "Menelusuri Nilai-Nilai Karakter dalam pantun (Inovasi Penggalian Bahan Ajar Bahasa dan Sastra Indonesia untuk Pendidikan Dasar dan Menengah)" Pedagogia. 399 (diakses 3 Juni 2021).

Ririn, A., N., "Sastra Dalam Pembentukan Karakter siswa “. (63-73)

Jurnal Edukasi Kultura. 2 no.2( September 2015): 63-73 (diakses 3 Juni 2021).

\section{BIOGRAFI PENULIS}

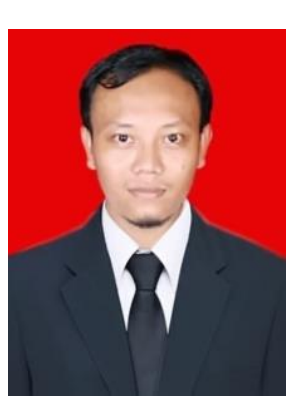

Nama : Ali Wardana

Alamat : Desa Jetis, Rt 04 Rw 02, Kecamatan Kemangkon, Kabupaten Purbalingga, Jawa Tengah

Lahir di sebuah desa terpencil di pinggiran sungai Klawing Purbalingga pada tanggal 4 Juni 1984, saat ini bekerja di MI Negeri 3 Purbalingga dan sedang melanjutkan study di UIN Saizu Purwokerto

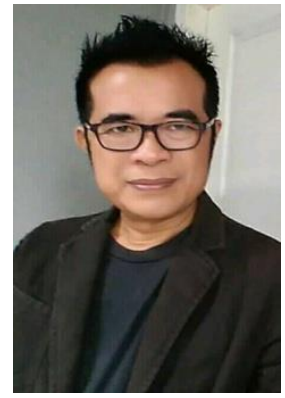

Abdul Wachid Bambang Suharto, S.S., M.Hum. atau akrab disapa Abdul Wachid B.S. dan AWBS adalah seorang akademisi dan sastrawan Indonesia. Dia adalah staf pengajar IAIN Purwokerto yang sekarang menjadi UIN Prof. K.H. Saifuddin Zuhri Purwokerto dan Universitas Ahmad Dahlan. Di dunia sastra, Abdul Wachid B.S. dikenal dari karya puisi yang dihasilkannya, dilahirkan di Bluluk, Tanggal 7 Oktober 1966 (usia 54 tahun), diantara karyanya antara lain Rumah cahaya: sepilihan sajak, Sastra pencerahan, dan banyak lagi yang lainya 